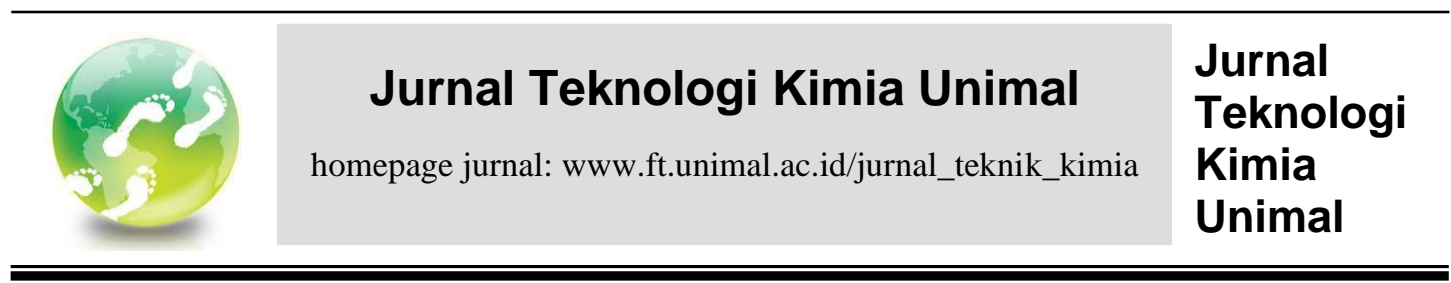

\title{
PRODUKSI GAS HIDROGEN DARI AIR LAUT DENGAN METODE ELEKTROLISIS MENGGUNAKAN ELEKTRODA TEMBAGA DAN ALUMUNIUM (Cu DAN Al)
}

\section{Muhammad Fazlunnazar, Lukman Hakim, Meriatna, Sulhatun, Muhammad Mizra Aminullah}

Jurusan Teknik Kimia, Fakultas Teknik, Universitas Malikussaleh, Kampus Bukit Indah Lhokseumawe email: muhammadfazlun13@gmail.com

\begin{abstract}
Abstrak. Hidrogen merupakan salah satu energi terbarukan yang mempunyai banyak kelebihan dibanding dengan energi terbarukan lainnya. Salah satu metode yang menjanjikan untuk menghasilkan gas hidrogen adalah dengan metode elektrolisis air laut yang sumbernya tidak terbatas. Metode lektrolisis pada penelitian ini menggunakan arus listrik searah atau DC (Power Supply) dan air laut dengan volume elektrolit 1000 ml, waktu elektrolisis 2, 4, 6 dan 8 menit dengan menggunakan elektroda Tembaga (anoda) dan Alumunium (katoda) pemilihan jenis reaktor berbentuk silinder volume $1500 \mathrm{ml}$, kondisi operasi $30^{\circ} \mathrm{C}$ dan $1 \mathrm{~atm}$. Adapun yang menjadi variabel bebas yaitu tegangan 5, 10, 15, 20 dan 25 volt. Dengan variasi waktu hasil kajian menunjukkan bahwa tegangan sangat berpengaruh terhadap penguraian air laut menjadi gas hidrogen. Hasil flow rate gas hidrogen yang paling tinggi di dapat pada tegangan 20 volt dengan waktu 6 menit sebesar 1,8182 cc/det (6545,52 ml/jam). Hasil kajian waktu elektrolisis terhadap penguraian air laut menjadi gas hidrogen tidak berpengaruh signifikan, waktu elektrolisis 6 dan 8 menit pada tegangan 20 dan 15 volt menunjukkan hasil gas hidrogen yang tinggi.
\end{abstract}

Kata kunci : Hidrogen, flow rate, elektroda, energi.

Abstract. Hydrogen is a renewable energy that has many advantages compared to other renewable energy sources. One promising method for producing hydrogen gas is the electrolysis method of seawater with unlimited sources. The electrolysis method in this study uses a DC or DC (Power Supply) electric power and sea water with an electrolyte volume of $1000 \mathrm{ml}$, electrolysis time of 2, 4, 6 and 8 minutes using Copper (anode) and Aluminum (cathode) electrodes. cylinder volume $1500 \mathrm{ml}$, Operating Conditions 30oC and $1 \mathrm{~atm}$. While the variables are voltage 5, 10, 15, 20 and 25 volts. With time variations, the results of the study show that stress is very influential in decomposing sea air into hydrogen gas. The highest hydrogen gas flow rate at a voltage of 20 volts with a time of 6 minutes is $1.8182 \mathrm{cc} / \mathrm{sec}(6545.52 \mathrm{ml} /$ hour $)$. The results of the study of electrolysis 
time to decompose sea air into gas have no significant effect, electrolysis time of 6 and 8 minutes at voltages of 20 and 15 volts shows high hydrogen gas yields.

Keywords: Hydrogen, flow rate, electrodes, energy.

\section{PENDAHULUAN}

Krisis energi yang melanda Indonesia dikarenakan jumlah penduduk yang semakin meningkat berpengaruh langsung terhadap konsumsi bahan bakar. Di sisi lain, isu lingkungan global yang menuntut tingkat kualitas lingkungan yang lebih baik, mendorong berbagai pakar energi untuk mengembangkan energi yang lebih ramah lingkungan dan mendukung keamanan pasokan keseimbangan.

Energi merupakan salah satu komponen yang sangat penting bagi kehidupan manusia, karena segala aktivitas manusia relatif bergantung pada kesediaan energi yang cukup. Pada saat ini minyak bumi menjadi penopang mayoritas kebutuhan energi bahan bakar, dikarenakan hasil pengolahan yang beragam dapat dimanfaatkan bagi kehidupan manusia khususnya di bidang transportasi.

Penggunaan minyak bumi dalam bahan bakar minyak (BBM) merupakan salah satu bentuk pemanfaatan yang banyak diaplikasikan oleh manusia dalam aktivitas transportasi, salah satunya yakni penggunaan sepeda motor oleh masyarakat dalam beraktifitas sehari-hari. Di sisi lain juga konsumsi dan kebutuhan minyak bumi terus meningkat karena semakin banyak jumlah kendaraan bermotor dan kebutuhan hidup lain seperti kebutuhan dalam dunia industri. Besar ketergantungan manusia terhadap ketersediaan minyak bumi perlu di kurangi dikarenakan semakin lama ketersediaan minyak semakin menipis, (Kementerian ESDM, 2018).

Sebagai upaya dalam hal penghematan BBM guna mengatasi krisis ketersediaan energi, maka perlu adanya pengembangan-pengembangan energi alternatif terbarukan untuk memenuhi kebutuhan pasokan energi dalam negeri ini. Salah satu penelitian mengenai energi terbarukan pada saat ini dikembangkan adalah pemanfaatan bahan bakar hidrogen yang digunakan dalam Fuel Cell System.

Hidrogen sangat dimungkinkan menjadi alternatif bahan bakar masa depan. Proses produksi hidrogen dapatdilakukan secara biologi maupun secarakimiawi. Secara biologi (bioteknologi) adalahteknik pendaya gunaan organisme hidup ataubagiannya untuk membuat atau memodifikasisuatu produk dan meningkatkan/ memperbaikisifat organisme untuk penggunaan dan tujuankhusus seperti untuk pangan, farmasi dan energi. Proses secara kimiawi gas alam seperti metana, propana atau etana direaksikan dengan steam (aup air) pada suhu tinggi $\left(700-1000^{\circ} \mathrm{C}\right)$ dengan bantuan katalis, untuk menghasilkan hidrogen, karbon dioksidasi $\left(\mathrm{CO}_{2}\right)$ dan karbon monoksida (CO), (Djati H. Salimy, 2010).

Sebuah reaksi samping juga terjadi antara karbon monoksida dengan steam, yang menghasilkan hidrogen dan karbon dioksida. Gas hidrogen yang dihasilkan kemudian dimurniakan, dengan memisahkan karbon dioksida dengan penyerapan. Saat ini, steam reforming banyak digunakan untuk memproduksi gas hidrogen secara komersial di berbagai sektor industri, diantaranya industri pupuk dan hidrogen peroksida $\left(\mathrm{H}_{2} \mathrm{O}_{2}\right)$.

Gas hidrogen atau $\mathrm{H}_{2}$ memiliki banyak kegunaan dalam kehidupan sehari-hari. Gas hidrogen diperlukan dalam proses pembuatan amonia, dimana terjadi reaksi antara hidrogen dengan nitrogen. Gas hidrogen juga digunakan pada proses pembuatan metanol dalam reaksinya dengan $\mathrm{CO}_{2}$. Hidrogen juga senyawa yang dibutuhkan untuk salah satu metode pembuatan sumber energi yaitu Fuel Cell. 
Didalam bumi sendiri gas hidrogen bersenyawa dengan unsur oksigen yang membentuk senyawa $\mathrm{H}_{2} \mathrm{O}$ yang sering juga disebut dengan air. Dalam hal pembakaran gas hidrogen menghasilkan energi yang cukup besar. Hidrogen tidak tersedia di bumi dalam keadaan bebas melainkan diproduksi secara industri sehingga harga akhir dari gas hidrogen ditentukan melalui proses produksi yang digunakan (Vanags, 2012).

Gas hidrogen $\left(\mathrm{H}_{2}\right)$ dapat diperoleh salah satunya dengan metode elektrolisis air. Pemisahan gas hidrogen $\left(\mathrm{H}_{2}\right)$ dari molekul air dengan cara memasukkan arus listrik dengan besaran yang sesuai sehingga gas oksigen dan hidrogen dapat terpisahkan.

Air dapat berupa air tawar dan air asin (air laut) yang merupakan bagian terbesar dibumi ini. Di dalam lingkungan alam proses, perubahan wujud, gerakan aliran air (di permukaan tanah, di dalam tanah dan di udara) dan jenis air mengikuti suatu siklus keseimbangan dan dikenal dengan istilah siklus hidrologi (Kodoatie dan Sjarief, 2010).

Elektrolisis adalah metode sederhana produksi hidrogen. Arus listrik lemah dialirkan melalui listrik, dan gas oksigen terbentuk di anoda sementara gas hidrogen terbentuk dikatoda. Biasanya katoda terbuat dari platina atau logam inert lainnya ketika hidrogen diproduksi untuk disimpan. Namun jika gas akan dibakar ditempat, oksigen yang dihasilkan harus mendukung pembakaran, sehingga kedua elektroda harus terbuat dari bahan inert. Efesiensi maksimum teoritis adalah antara 80-94 \%. (Kruse, B ; dkk, 2002)

Metode elektrolisis merupakan proses kimia yang mengubah energi listrik menjadi energi kimia. Komponen terpenting dari sebuah elektrolisis adalah elektroda dan larutan elektrolit (martawati, 2014). Proses elektrolisis berjalan sangat lambat sehingga perlu diupayakan cara-cara untuk meningkatkan efisiensi produk, misalnya dengan penambahan zat terlarut yang bersifat elektrolit (Isana, 2010). Zat terlarut tersebut misalnya garam.

\section{METODOLOGI}

Pada proses pembuatan gas hidrogen ini menggunakan reaktor elektrolisis dengan bahan baku air laut (laut bangka). Dalam prosedur penelitian pembuatan gas hidrogen dari air laut dengan metode elektrolisis dilakukan tiga tahapan. Tahapan pertama persiapan alat dan bahan, tahapan kedua pembuatan gas hidrogen, dan tahapan ketiga analisa gas hidrogen.

Tahap persiapan alat dan bahan dilakukan dengan persiapan elektroda pada reaktor elektrolisis pada reaktor elektrolisis dan pengambilan bahan baku air laut. Proses pembuatan gas hidrogen dengan merangkaikan peralatan, masukkan cairan elekrolit (air laut) kedalam reaktor sebagai variabel tetap sebanyak $1000 \mathrm{ml}$, menggunakan elektroda kawat tembaga-alumunium pada reaktor dan hidupkan power supplay diatur pada tegangan 5 volt pertama dan variasi variabel bebas 10, 15, 20 dan 25 volt, dengan waktu elektrolisis sebagai variabel bebas 2, 4, 6, 8 menit.

Analisa gas hidrogen dibagi dalam tiga tahapan diantaranya: analisa gelembung gas hidrogen, menghitung flow rate gas hidrogen, analisa uji bakar gas hidrogen. Untuk analisa gelembung gas hidrogen, gas keluaran dari reaktor dimasukkan kedalam beaker glass yang telah diisi dengan air sabun. Gas yang di hasilkan akan masuk ke dalam air memberikan tekanan sehingga menghasilkan gelembung-gelembung gas. Dilakukan pengamatan pada gelembung gas yang terbentuk dalam beaker glass dari tiap-tiap variabel tegangan.

Menghitung flow rate gas hidrogen, keluaran dari reaktor dihubungkan dengan bubble flow meter. Dilakukan pengamatan dengan memberikan tekanan pada balon yang 
terhubung pada bubble flow meter. Cairan dalam bubble flow meter akan menghasilkan gelembung, gelembung akan di dorong oleh gas hidrogen yang masuk. Menghidupkan stopwatch ketika gelembung berada pada garis batas $0 \mathrm{cc}$ dan menghentikan stopwatch jika gelembung berada pada salah satu garis batas yang di pilih. Menghitung jumlah flow rate gas dengan rumus:

$$
\text { Flow rate }=\frac{\text { Garis batas akhir yang dipilih }}{\text { waktu pengamatan stopwatch }}
$$

Analisa uji bakar gas hidrogen, gas hidrogen dari reaktor ditampung ke dalam tabung reaksi selama beberapa detik. Setelah selesai di tampung, akhiri sementara proses elektrolisis dan nyalakan api pada permukaan tabung reaksi. Harus berhati-hati dalam melakukannya di karenakan sifat dari pada gas hidrogen yang mudah terbakar akan menghasilkan letupan.

Berikut diagram kerja dari proses pembuatan gas hidrogen dari air laut dengan metode elektrolisis.

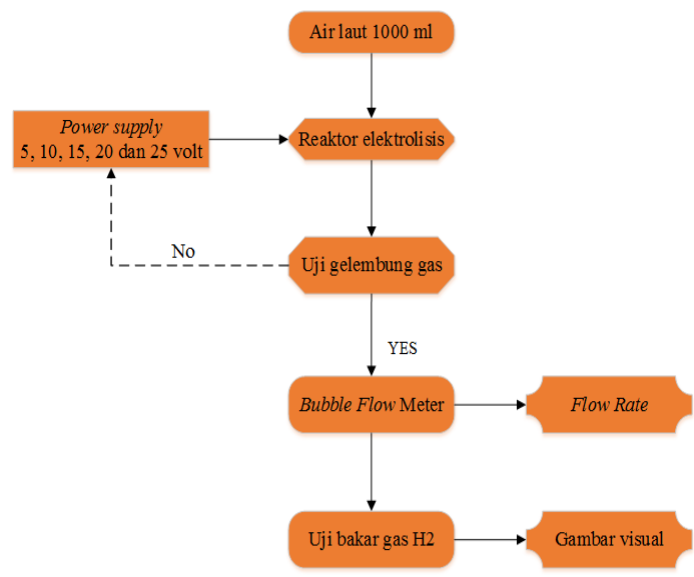

\section{HASIL DAN PEMBAHASAN}

Proses elektrolisis merupakan proses yang menggunakan energi listrik agar reaksi kimia nonspontan dapat terjadi. Pada penelitian pembuatan gas hidrogen ini, jenis elektroda yang digunakan adalah tembaga dengan alumunium. Dasar pemilihan elektroda ini berlandaskan pada nilai konduktivitas yang dimiliki oleh tembaga, tembaga memiliki nilai konduktivitas yang tinggi.

Cairan elektrolit yang digunakan adalah air laut dengan volume $1000 \mathrm{ml}$. Proses elektrolisis memerlukan aliran listrik searah, sumber listrik diperoleh dari power supplay DC sebagai outputnya dengan tegangan minimal 5 volt dan maksimal 25 volt. Pada proses elektrolisis terjadi pelepasan gas hidrogen terjadi pada katoda, seperti yang dapat kita lihat pada reaksi yang terjadi sebagai berikut:

Anoda:

$$
\begin{aligned}
& 2 \mathrm{H}_{2} \mathrm{O}_{(\mathrm{l})} \rightleftarrows 4 \mathrm{H}^{+}(\mathrm{aq})+\mathrm{O}_{2}(\mathrm{~g})+4 \mathrm{e}(\text { Oksidasi }) \\
& 2 \mathrm{NaCl}^{-}(\mathrm{g}) \rightleftarrows \quad 2 \mathrm{Na}^{+}(\mathrm{ag})+\mathrm{Cl}_{2(\mathrm{~g})}+2 \mathrm{e}^{-} \\
& \mathrm{Cl}_{2(\mathrm{~g})}+\mathrm{H}_{2} \mathrm{O} \rightleftarrows \mathrm{HCl}_{(\mathrm{ag})}+\mathrm{HOCl}_{(\mathrm{ag})} \\
& \text { Katoda: } \\
& 2 \mathrm{H}_{2} \mathrm{O}_{(\mathrm{l})}+2 \mathrm{e}^{\leftrightarrows} \mathrm{H}_{2(\mathrm{~g})}+2 \mathrm{OH}_{(\mathrm{ag})}^{-} \text {(Reduksi)+ } \\
& 2 \mathrm{NaCl}+2 \mathrm{OH}^{-}\left(\text {aq) } \quad 2 \mathrm{NaOH}+\mathrm{Cl}^{-}(\mathrm{l})\right. \\
& \text { Total: } \\
& 2 \mathrm{NaCl}_{(\mathrm{aq})}+\mathrm{H}_{2} \mathrm{O}_{(\mathrm{l})} \mathrm{NaOCl}_{(\mathrm{s})}+\mathrm{H}_{2(\mathrm{~g})}(\text { Redoks) }
\end{aligned}
$$


Prinsip kerja pada sel elektrolisis berlawanan dengan sel volta, sehingga susunan rangkaian sel elektrolisis juga berlawanan dengan susunan rangkaian sel volta. Pada sel elektrolisis, anoda bermuata positif (+) sedangkan katoda bermuatan negatif (-).

\subsection{Pengaruh Waktu Elektrolisis dan Tegangan Terhadap Flow Rate Gas Hidrogen}

Dalam penelitian pembuatan gas hidrogen dengan metode elektrolisis pengaruh waktu dan tegangan terhadap flow rate gas hidrogen dapat dilihat pada gambar 3.1 di bawah ini.

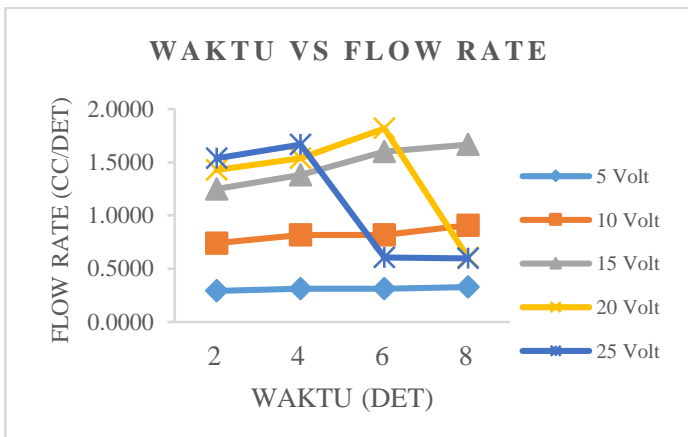

Gambar 3.1 Hubungan Waktu Elektrolisis dan Tegangan Terhadap Flow Rate Gas Hidrogen.

Hasil dari pengamatan diatas pada penelitian produksi gas hidrogen dengan metode elektrolisis, dapat kita lihat pada waktu elektrolisis tidak berpengaruh secara signifikan dalam menghasilkan flow rate gas hidrogen. Sehingga dapat kita simpulkan bahwa penguraian air laut menjadi gas hidrogen tidak terlalu berpengaruh terhadap lamanya waktu elektrolisis. Hal ini di sebabkan untuk penguraian $\mathrm{H}_{2} \mathrm{O}$ di perlukan energi yang tinggi, sel elektrolisis memerlukan energi untuk memompa elektron (Brandy 2019). Namun pada waktu 6 dan 8 menit adanya penurunan flow rate gas hidrogen, hal ini di sebabkan oleh faktor terdegradasi yang terjadi pada elektroda sehingga proses trasnfer elektron tidak dapat berjalan dengan sempurna.

Berdasarkan pengamatan di atas pada besaran tegangan yang diberikan, menghasilkan flow rate gas hidrogen yang berbeda-beda. Dari grafik diatas dapat kita lihat semakin besar tegangan yang di berikan maka flow rate gas hidrogen dan endapan yang di hasilkan juga semakin besar. Hal ini berbanding lurus dengan bunyi hukum Faraday I : Jumlah zat yang dihasilkan pada elektroda berbanding lurus dengan jumlah arus listrik yang melalui elektrolisis. Namun pada tegangan 20 dan 25 volt adanya sedikit penurunan pada flow rate gas hal ini sebabkan oleh faktor terdegradasi yang terjadi pada elektroda, sehingga proses transfer elektron dari elektroda ke dalam elektrolit tidak sempurna.

Hasil dari penelitian produksi gas hidrogen dengan metode elektrolisis, flow rate tertinggi gas hidrogen di dapat pada tegangan 20 volt dengan waktu elektrolisis 6 menit di peroleh flow rate gas hidrogen sebesar $1,8182 \mathrm{cc} / \mathrm{det}(6545,52 \mathrm{ml} / \mathrm{jam})$.

\subsection{Pengaruh Waktu Elektrolisis dan Tegangan Terhadap Temperatur}

Pengaruh waktu dan tegangan terhadap temperatur yang di hasilkan pada penelitian pembuatan gas hidrogen dengan metode elektrolisis, dapat dilihat pada gambar 3.2 di bawah ini. 


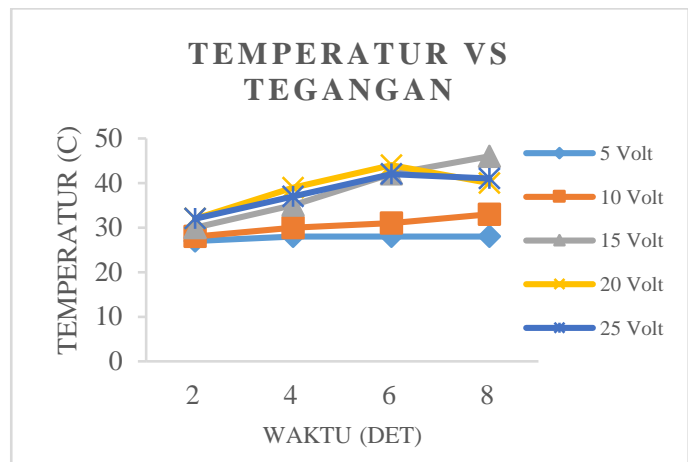

Gambar 3.2 Hubungan Waktu dan Tegangan Terhadap Temperatur

Hasil pengamatan pengaruh waktu terhadap suhu reaksi yang di hasilkan, dapat kita lihat hasil yang di dapatkan terhadap kenaikan temperatur dengan waktu elektrolisis terjadi kenaikan secara signifikan. Namun pada tegangan 5 dan 10 volt tidak ada kenaikan secara signifikan, karena energi yang di transfer tidak terlalu besar. Dari pengamatan di atas, dapat di simpulkan bahwa perubahan suhu reaksi berbanding lurus dengan lamanya waktu elektrolisis. Namun pada waktu 8 menit dengan tegangan 20 dan 25 volt adanya penurunan hal ini di sebabkan oleh terdegradasi elektroda sehingga proses transfer energi tidak sempurna.

Hasil dari pengamatan pengaruh tegangan terhadap perubahan suhu dapat kita lihat, semakin besar tegangan yang diberikan maka semakin besar pula perubahan suhu yang terjadi. Hal ini di karenakan oleh transfer energi, di mana semakin besar tegangan maka energi yang di transfer semakin besar pula. Namun pada tegangan 20 dan 25 volt adanya penurunan suhu yang terjadi, faktor ini di sebabkan oleh terdegradasi yang terjadi pada elektroda sehingga energi yang di transfer tidak sempurna masuk ke dalam elektrolit. Dari garfik di atas hasil penelitian yang di dapat terhadap perubahan suhu yang tertinggi terjadi pada tegangan 15 volt dengan waktu elektrolisis 8 menit.

\subsection{Pengujian Gas Hidrogen Terhadap Pembakaran}

Hidrogen dicampur dengan oksigen dalam berbagai perbandingan, hidrogen akan menghasilkan suara letupan meledak seketika bila disulut dengan api dan akan meledak dengan sendirinya pada temperatur $560{ }^{\circ} \mathrm{C}$. Hasil pembakaran hidrogen dan oksigen murni memancarkan gelombang ultraviolet dan hampir tidak bisa terlihat dengan mata telanjang. Sehingga sangat sulit untuk mendeteksi kebocoran gas hidrogen. Berikut dapat kita lihat pada gambar 3.3 pengujian gas hidrogen terhadap pembakaran:

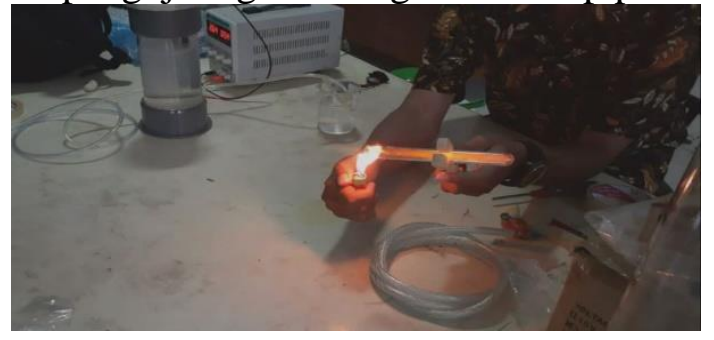

Gambar 3.3 Uji Bakar Gas Hidrogen

Dalam pengujian bakar gas hidrogen, mula-mula gas hidrogen yang di hasilkan di tampung ke dalam tabung reaksi dengan permukaan tabung reaksi di balik menghadap ke bawah. Hal ini bertujuan agar gas yang di tampung tidak mudah keluar dari tabung karena gas hidrogen yang ringan sangat lah mudah menguap ke udara. Setelah gas di tampung beberapa detik maka proses elektrolisis di hentikan sementara, kemudian nyalakan api pada permukaan tabung reaksi dengan posisi tabung memiliki sudut $45^{\circ}$. Gas hidrogen 
yang berjumpa dengan lidah api akan terbakar dan mengahasilkan letupan, hal ini sesuai dengan teori-teori yang menjelaskan bahwa Gas hidrogen yang terbakar oleh api akan meletup, sesui dengan sifat yang di miliki gas hidrogen. Namun bila pada pembakaran tidak meletup, gas hidrogen telah bereaksi dengan oksigen sehingga membentuk uap air. Dalam hal ini di buktikan dengan reaksi pembentukan uap air:

$$
\rightarrow \quad 2 \mathrm{H}_{2(\mathrm{~g})}+\mathrm{O}_{2(\mathrm{~g})} \quad 2 \mathrm{H}_{2} \mathrm{O}_{(\mathrm{l})}
$$

Api yang dinyalakan pada ujung tabung reaksi ikut memenuhi tabung reaksi, hal ini bisa kita lihat dengan konsep segitiga api. Seperti pada gambar 3.4

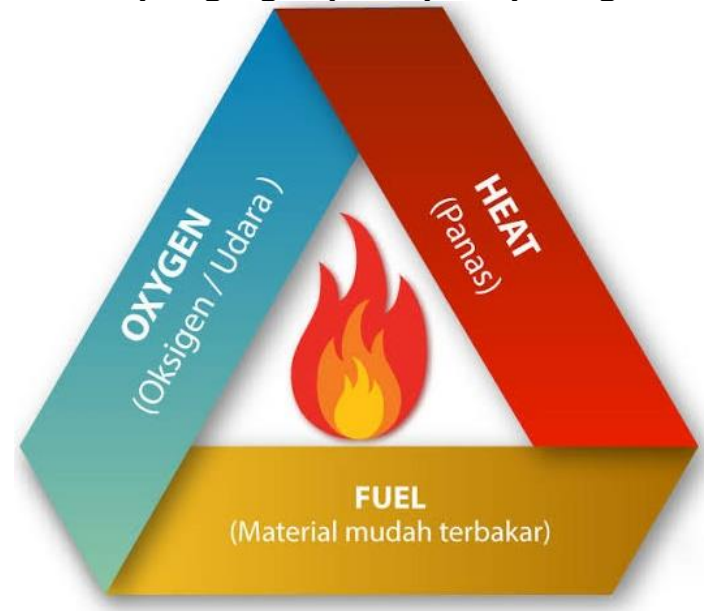

Gambar 3.4 Teori Segitiga Api

Dimana segitiga api memiliki unsur-unsur di antaranya : api, oksigen dan bahan bakar, maka dari pembakaran di atas bisa kita simpulkan bahwa api yang menyala dalam tabung reaksi di karenakan adanya gas hidrogen yang mengisi tabung sehingga api yang menyala di permukaan tabung ikut menyulut dan membakar habis gas hidrogen yang ada di dalam tabung rekasi tersebut.

\section{Kesimpulan}

Penelitian produksi gas hidrogen dari air laut dengan metode elektrolisis yang telah dilaksanakan, dapat diambil beberapa kesimpulan antara lain:

1. Tegangan (volt) memiliki peran yang sangat berpengaruh terhadap flow rate gas hidrogen yang terbentuk.

2. Waktu elektrolisis tidak berpengaruh signifikan terhadap laju gas hidrogen yang di hasilkan.

3. Hasil terbaik yang didapat dari produksi gas hidrogen terdapat pada tegangan 20 volt, dengan jumlah gas yang dihasilkan sebesar 1,8182 cc/det (6545,52 ml/jam) dan transfer arus listrik ke sel dapat merata dan konstan.

4. Elektroda tembaga dan alumunium mudah terjadinya degradasi dan dapat menghambat proses produksi gas hidrogen.

\section{REFERENSI}

Brady, J.E. 1999. General Chemistry Principles and structure. Jakarta: Binarupa Aksara. Djati H. Salimy, (2010). Produksi Hidrogen Proses Steam Reforming Dimethyl Ether (DME) Dengan Reaktor Nuklir Temperatur Rendah. Pusat Pengembangan Energi Nuklir (PPEN) Batan.

Dhamadharma, (2010). Salinitas Laut, di 
https://dhamadharma.wordpress.com/2010/02/11/salinitas-laut/ (di akses 01 November)

Emsley, John (2001). Nature's Building Blocks. Oxford: Oxford University Press. hlm. 183-191. ISBN 0-19-850341-5.

Engelhardt viktor., "Elektrolysys of Water Processes and Application Handbook", Chief Engineer and Chemist of the Siemens and Halske. Co., Limited, Vienna, 1904)

Erwin Walad, 2007. Evaluasi Penggunaan Single Colomn dan Multi Column pada Gas Chromatography dalam penentuan komposisi gas alam. Universitas Malikussaleh. Lhokseumawe

Funderburg, E. (2008) “Why Are Nitrogen Prices So High?”. The Samuel Roberts Noble Foundation. Diakses tanggal 11 Februari 2019

Isana, S. Y. L., 2010, Perilaku Sel Elektrolisis Air dengan Elektroda Stainlees Steal, Jurnal Kimia UNY, ISBN:978-97998117-7-6.

Kodoatie, Robert J., dan Roestam, Sjarief, 2010. Tata Ruang Air. Yogyakarta: Andi.

K. Onuki, et.al., "R\&D on Nuclear Hydrogen Production using HTGR at JAERI", COEINES International Symposium, Tokyo, (2004).

Kruse, B. Grinna, S. Buch, C. (2002). "Hydrogen Status og Muligheter" (PDF).

Kementerian ESDM. (2018). Angka Cadangan Migas Di Indonesia, di https://www.esdm.go.id.

Leanne M. Crosbie, Hydrogen Production by Nuclear Heat. MPR Associated, Kyoto Japan, sep. 15-19,2003.

Martawati, M. E., 2014 Sistem Elektrolisis Air sebagai Bahan Bakar Alternatif pada Kendaraan, Jurnal Eltek, 12 (1):93-104.

Marum. (2019) di https://www.marum.de/wir-ueber-uns/Hinrichslab-GC-MS.html (di akses 10 Oktober 2019)

Oxtoby, D. W. (2002). Principles of Modern Chemistry (edisi ke-5th). Thomson Brooks/Cole. ISBN 0-03-035373-4.

Romdhani, 2017. Elektrokimia (vol 3). Universitas Gunadarma, Depok.

Riley, J. p., Skirrow G. 1975., Chemical Oceanography, v.4 2nd ed. Academic Press, London, San Francisco.

Stwertka, Albert (1996). A Guide to the Elements. Oxford University Press. hlm. 16-21. ISBN 0-19-508083-1. 
Surdia, T. Saito, S., 1992, Pengetahuan Bahan Teknik, PT. Pradnya Paramita, Jakarta.

Sigmaaldrich, (2019). Di https://www.sigmaaldrich.com/catalog/product/sepelco/ (di akses 12 Oktober 2019).

Vanags, M., Janis, K, \& Gunars, B. (2012). Water Elektrolysis with Inductive Voltage Pulses. Journal of Intech, 2.

Venere, E. (15 May 2007). “New process generates hydrogen from aluminum alloy to run engines, fuel cells" purdue University. Di akses tanggal 07 February 2019

Winter, Mark (2007). “Hydrogen: historical information” dalam www. id.wikipedia.org. 05-02-2019. 